\title{
Roles of SIRT1 and Phosphoinositide 3-OH Kinase/Protein Kinase C Pathways in Evodiamine-Induced Human Melanoma A375-S2 Cell Death
}

\author{
Che Wang ${ }^{1,2}$, Min-wei Wang ${ }^{2}$, Shin-ichi Tashiro ${ }^{3}$, Satoshi Onodera ${ }^{3}$, and Takashi Ikejima ${ }^{1, *}$ \\ ${ }^{1}$ China-Japan Research Institute of Medical and Pharmaceutical Sciences, and ${ }^{2}$ Department of Pharmacology, \\ Shenyang Pharmaceutical University, 103 Wenhua Road, Shenyang 110016, China \\ ${ }^{3}$ Department of Clinical and Biomedical Sciences, Showa Pharmaceutical University, Tokyo 194-8543, Japan
}

Received December 3, 2004; Accepted February 9, 2005

\begin{abstract}
We previously demonstrated that evodimine isolated from Evodia rutaecarpa (Goshuyu in Japan) induced apoptosis in human malignant melanoma A375-S2 cells within $24 \mathrm{~h}$. In this study, TUNEL assay also indicated that one cause of A375-S2 cell death induced by evodiamine was apoptosis. After treatment with evodiamine for the indicated time periods, antiapoptotic protein SIRT1 expression was decreased; p53 expression and its phosphorylation were both enhanced, whereas transient induction of downstream p21 was not enough to promote cell cycle arrest. Inhibition of the phosphoinositide 3-OH kinase (PI3-K)/protein kinase C (PKC) survival pathway as well as subsequent inhibition of the ERK cascade might contribute to evodiamine-induced cell death. In addition, p53 activation in response to evodiamine administration was correlated with the activation of the PI3-K/PKC pro-apoptotic pathway, but did not require ERK participation. The inhibition of the PI3-K/PKC survival pathway might be responsible for SIRT1 inactivation and increased $\mathrm{Bax} / \mathrm{Bcl}-2$ expression ratio in evodiamineinduced cell death.
\end{abstract}

Keywords: evodiamine, SIRT1, phosphoinositide 3-OH kinase, protein kinase C, p53

\section{Introduction}

Evodiamine (Fig. 1), a constituent isolated from the dried, unripe fruit of Evodia rutaecarpa (Goshuyu in Japanese) has been reported to present bronchial contractive (1), catecholamine secretory (2), vasodilatory $(3,4)$, anti-nociceptive (5), and antitumor effects (6). It was also reported that evodiamine had an inhibitory effect on tumor cell migration in vitro (7). Our previous study has shown that in evodiamine-induced A375-S2 cell death, down-regulation of Bcl-2 and up-regulation of Bax amplified the activation of the caspase cascade. Additionally, simultaneous activation of p38 MAPK and inhibition of ERK activity contributed to this cell death $(8,9)$. In this study, it is further demonstrated that PI3-K and PKC exhibit important regulatory effects on functions of SIRT1, p53, ERK, and Bcl-2 family proteins in evodiamine-induced A375-S2 cell death.

It has been shown that DNA damage-induced acti-

*Corresponding author. FAX: +86-24-2384-4463

E-mail: ikejimat@vip.sina.com vation of p53 protein leads to either growth arrest or apoptosis $(10,11)$, and phosphorylation of $\mathrm{p} 53$ at serine 20 enhances induction of its downstream p21 $(12,13)$. The Bcl-2 family was known to play an essential role in DNA damage-induced apoptosis, and the balance

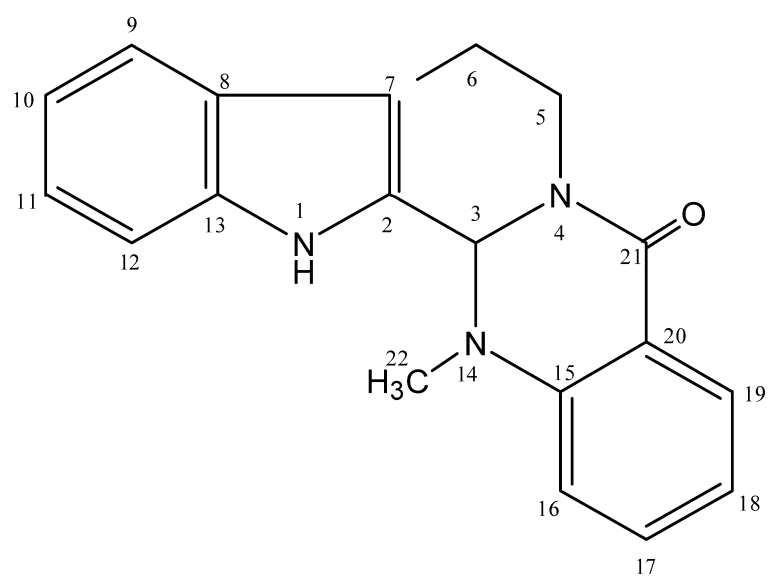

Fig. 1. Structure of evodiamine. 
between proapoptotic proteins (Bax, Bad) and antiapoptotic proteins $\left(\mathrm{Bcl}-2, \mathrm{Bcl}-\mathrm{x}_{\mathrm{L}}\right)$ determine the fate of cells $(14,15)$. Bax relocalizes to the outer mitochondrial membrane to initiate the release of cytochrome $c$, with downstream events including caspase activation and cleavage of their substrates (16). In addition, Bax can be directly activated by p53 in triggering apoptosis $(17,18)$.

SIRT1 is a key regulator involved in cell aging and the response to DNA damage (19). SIRT1 is a member of the sirtuin family of nicotinamide adenine dinucleotide $\left(\mathrm{NAD}^{+}\right)$-dependent deacetylase and known to inhibit stress-induced apoptosis $(19,20)$. It not only regulates p53 function via deacetylation with a specificity for p53 C-terminal Lys382 residue, modification of which has been implicated in the activation of p53 as a transcription factor (20), but also inhibits stress-induced apoptotic cell death by deacetylating the DNA repair factor $\mathrm{Ku} 70$ that is tightly associated with Bax, causing it to sequester Bax away from mitochondria (21).

It is now clear that activation of the phosphoinositide 3-OH kinase (PI3-K) pathway was capable of conferring protection from $\mathrm{p} 53$-mediated apoptosis $(11,22)$ and the p53 induction activated the Ras/Raf/MAPK cascade (23). Among the MAPK family, ERK signaling in the regulation of cell growth and differentiation is controversial. It can be activated by growth factors, resulting in protection against cell death (24). Moreover, it has also been reported that ERK promoted apoptosis in response to certain chemotherapeutic agents (25).

$\mathrm{PKC}$ is a group of serine/threonine kinases that plays an important role in tumor cell proliferation and invasion $(26,27)$. Constitutively activated cell surface receptors such as the EGF (epidermal growth factor) receptor or the PDGF (platelet-derived growth factor) receptor that release signal through PI3-K (28) may cause hyperactivation of PKC as well as subsequent MAPK/ERK cascade (29). Another downstream signaling target of $\mathrm{PKC}$ is the antiapoptotic protein $\mathrm{Bcl}-2(30,31)$.

In view of the close biochemical relations in the signaling pathways described above, we speculated that reduced SIRT1 expression and activated p53 might participate in evodiamine-induced A375-S2 cell death, and both the PI3-K inhibitor wortmannin and PKC inhibitor staurosporine downregulated SIRT1 and p53 expressions, resulting in reduction of ERK activity and decreased expression of Bcl-2. Bax expression was enhanced by PI3-K inhibition, but was independent of the PKC pathway.

\section{Materials and Methods}

\section{Reagents}

Evodiamine was obtained from Beijing Institute of
Biological Products (Lot: 0802-9702, Beijing, China); and its purity was determined to be about $98 \%$ by HPLC measurement. Evodiamine was dissolved in dimethyl sulfoxide (DMSO) to make a stock solution and diluted by RPMI-1640 (Gibco, Grand Island, NY, USA) before the experiments. DMSO concentration in all cell culture was kept below $0.01 \%$, which had no detectable effect on cell growth or death.

The TACS ${ }^{\mathrm{TM}} 2$ TdT-DAB In Situ Apoptosis Detection Kit was purchased from Trevigen (Gaithersburg, MD, USA). The PI3-K family inhibitor wortmannin and protein kinase $\mathrm{C}$ inhibitor staurosporine were purchased from Sigma (St. Louis, MO, USA), The ERK inhibitor (PD98059) was from Calbiochem (La Jolla, CA, USA). Rabbit polyclonal antibodies against SIRT1, phosphop53, ERK, Bax, mouse polyclonal antibody against p53, phospho-ERK, Bcl-2, and horseradish peroxidaseconjugated secondary antibodies were obtained from Santa Cruz Biotechnology (Santa Cruz, CA, USA).

\section{Cell culture}

A375-S2, human melanoma cells, were obtained from American Type Culture Collection (ATCC, \#CRL, 1872, MD, USA) and were cultured in RPMI-1640 medium supplemented with $10 \%$ heat inactivated $\left(56^{\circ} \mathrm{C}\right.$, $30 \mathrm{~min}$ ) fetal calf serum (Beijing Yuanheng Shengma Research Institution of Biotecnology, Beijing, China), $2 \mathrm{mM}$ L-glutamine (Gibco, Grand Island, NY), $100 \mathrm{kU}$ $/ \mathrm{L}$ penicillin, and $100 \mathrm{mg} / \mathrm{L}$ streptomycin (Gibco) at $37^{\circ} \mathrm{C}$ in $5 \% \mathrm{CO}_{2}$. Cells in the exponential phase of growth were used in the experiments.

\section{Terminal deoxynucleotidyl transferase-mediated dUTP nick end-labeling (TUNEL) Assay}

The TUNEL Assay was used for detection of DNA strand breaks. The detection was carried out according to the instructions of the TACS ${ }^{\mathrm{TM}} 2$ TdT-DAB In Situ Apoptosis Detection Kit. Briefly, the cells were rinsed once with PBS and fixed in $3.7 \%$ buffered formaldehyde at room temperature for $10 \mathrm{~min}$. The fixed sections were pretreated with $10 \% \mathrm{H}_{2} \mathrm{O}_{2}$, and end-labeling was performed with TdT labeling reaction mix for $37^{\circ} \mathrm{C}$ for $1 \mathrm{~h}$. Nuclei exhibiting DNA fragmentation were visualized by incubation in 3',3-diamino benzidine (DAB) for $7 \mathrm{~min}$. Finally, the sections were counterstained with methyl green and observed by light microscopy. The nuclei of apoptotic cells were stained dark brown, and TUNEL-positive A375-S2 cells were determined by randomly counting 100 cells.

\section{Cytotoxicity assay}

A375-S2 cells were dispensed in 96-well flat bottom microtiter plates (NUNC, Roskilde, Denmark) at a 
density of $5 \times 10^{4}$ cells per well. After 12 -h incubation, they were treated with or without PI3-K, PKC, ERK inhibitors, $1 \mathrm{~h}$ prior to the administration of $15 \mu \mathrm{M}$ evodiamine. Then the cells were cultured for a further $24 \mathrm{~h}$, and $15 \mu \mathrm{L}$ MTT solution $(5.0 \mathrm{mg} / \mathrm{L})$ was added to each well followed by 4-h coincubation; the resulting crystals were dissolved in DMSO. Absorbance was measured with a plate reader (Bio-Rad, Hercules, CA, USA). The percentage of cell growth inhibition was calculated as follows:

Cell death (\%)

$$
=\left[\mathrm{A}_{570}(\text { control })-\mathrm{A}_{570}\right] / \mathrm{A}_{570}(\text { control }) \times 100
$$

\section{Western blot analysis}

A375-S2 cells were treated with $15 \mu \mathrm{M}$ evodiamine for $0,6,12,24$, and $48 \mathrm{~h}$ or pre-incubated with or without the given inhibitors for $1 \mathrm{~h}$, followed by treatment with evodiamine for another $24 \mathrm{~h}$. Both adherent and floating cells were collected. Then Western blot analysis was carried out with some modifications (32). Briefly, the cell pellets were resuspended in lysis buffer, including $50 \mathrm{mM}$ Hepes, $\mathrm{pH} 7.4,1 \%$ Triton$\mathrm{X} 100,2 \mathrm{mM}$ sodium orthovanadate, $100 \mathrm{mM}$ sodium fluoride, $1 \mathrm{mM}$ edetic acid, $1 \mathrm{mM}$ PMSF (Sigma), $10 \mu \mathrm{g}$ $/ \mathrm{mL}$ aprotinin (Sigma), $10 \mu \mathrm{g} / \mathrm{mL}$ leupeptin (Sigma), and lysed on ice for $60 \mathrm{~min}$. After centrifugation of the cell suspension at $13,000 \times g$ for $15 \mathrm{~min}$, the protein content of supernatant was determined by Bio-Rad protein assay reagent (Bio-Rad). The protein lysates were separated by electrophoresis in $12 \%$ SDS polyacrylamide gel electrophoresis and blotted onto a nitrocellulose membrane (Amersham Biosciences, Piscataway, NJ, USA). After blocking with Tween 20-Trisbuffer saline [50 mM Tris- $\mathrm{HCl}(\mathrm{pH} 7.5), 150 \mathrm{mM} \mathrm{NaCl}$, and $0.02 \%$ Tween 20 ] containing $5 \%$ nonfat milk at room temperature, the membrane was incubated with the indicated antibodies in blotting buffer. Primary antibodies and diluted concentrations used were: SIRT1 (1:500), p53 and phospho-p53 (1:200), ERK and phospho-ERK (1:1000), and Bax and Bcl-2 (1:200). The secondary antibodies used for these proteins were goat anti-rabbit $\operatorname{IgG}(1: 500)$, goat anti-mouse $\operatorname{IgG}(1: 500)$ conjugated with horseradish peroxidase (HRP), respectively, and 3,3-diaminobenzidine tetrahydrochloride as the substrate of HRP.

\section{Statistical analyses}

The results are presented as Mean \pm S.D. Significant changes were assessed using Student's $t$-test for unpaired data, and $P$-values $<0.05$ were considered statistically significant.

\section{Results}

Evodiamine induced A375-S2 cell apoptosis at early stage

Evodiamine induced A375-S2 cell death in a timeand dose-dependent manner (8), and $15 \mu \mathrm{M}$ evodiamine induced about $50 \%$ cell death at $24 \mathrm{~h}$ (9). To further determine the features of A375-S2 cell death, TUNEL assay was carried out. In the control group, the ratio of TUNEL-positive cells was $4.7 \pm 0.6 \%$. After treatment with $15 \mu \mathrm{M}$ evodiamine for 12 and $24 \mathrm{~h}$, apoptotic cell numbers increased to $21.2 \pm 1.5 \%$ and $38.7 \pm 2.8 \%$, respectively (Table 1). The percentage of TUNEL-positive cells at $24 \mathrm{~h}$ was more than that at $48 \mathrm{~h}$. These results indicated that the cause of A375-S2 cell death induced by evodiamine was mainly apoptosis before $24 \mathrm{~h}$.

In evodiamine-induced A375-S2 cell death, SIRT1 expression was down-regulated and p53 was activated

SIRT1 has been shown to be associated with apoptosis, and expression of inactive SIRT1 protein can potentiate $\mathrm{p} 53$ - or Bax-mediated apoptosis $(19,20)$. To confirm whether such a mechanism is involved in evodiamine-induced cell death, Western blot analysis was performed to detect the expression of SIRT1, p53, and its downstream p21. As shown in Fig. 2, after incubation with $15 \mu \mathrm{M}$ evodiamine for $0,6,12,24$, and

Table 1. Quantitive analysis of TUNEL-positive A375-S2 cells

\begin{tabular}{cc}
\hline Time $(\mathrm{h})$ & Apoptotic cells (\%) (TUNEL positive) \\
\hline 0 & $4.7 \pm 0.6$ \\
12 & $21.2 \pm 1.5^{*}$ \\
24 & $38.7 \pm 2.8^{* *}$ \\
48 & $29.3 \pm 3.1^{*}$ \\
\hline
\end{tabular}

The cells were treated with $15 \mu \mathrm{M}$ evodiamine for $0,12,24$, and $48 \mathrm{~h}$. The results are representative of three independent experiments. All data were presented as the mean \pm S.D. and considered statistically significant at $* P<0.1,{ }^{* *} P<0.01$ vs controls.

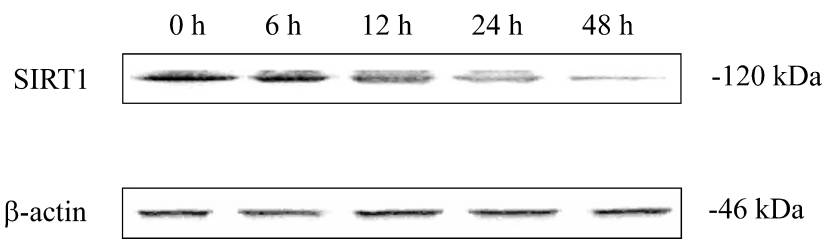

Fig. 2. SIRT1 protein expression in evodiamine-treated A375-S2 cells. The cells were treated with $15 \mu \mathrm{M}$ evodiamine for $0,6,12,24$, and $48 \mathrm{~h}$; cell lysates were separated by $12 \%$ SDS-PAGE; and the protein bands were detected by Western blot analysis. Triplicate experiments gave similar results. 


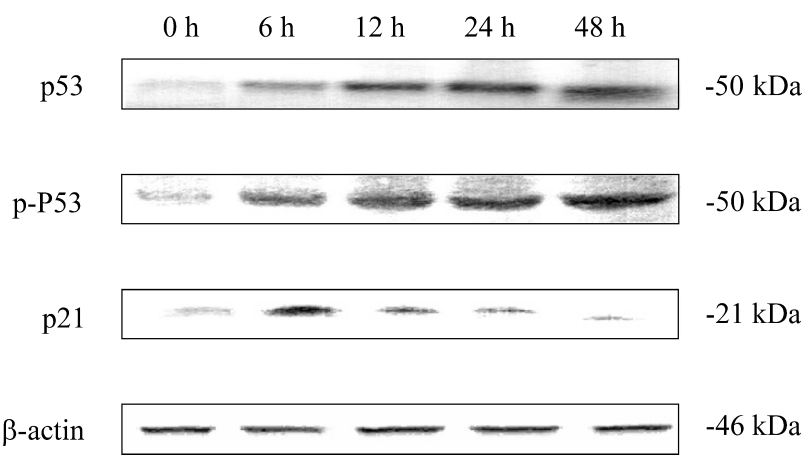

Fig. 3. Expression of p53, p21, and phosphorylation of p53 involved in evodiamine-induced cell death. The cells were treated with $15 \mu \mathrm{M}$ evodiamine for $0,6,12,24$, and $48 \mathrm{~h}$; and then expressions of p53, phospho-p53, and p21 were measured by Western blot analysis. Triplicate experiments gave similar results.

$48 \mathrm{~h}$, SIRT1 protein expression began to decrease at $12 \mathrm{~h}$. As expected, p53 and phosphorylated p53 were both activated in a time-dependent manner (Fig. 3). However, up-regulation of p21 occurred at 6-h incubation with evodiamine and then disappeared (Fig. 3), suggesting that transient induction of $\mathrm{p} 21$ was not enough to promote cell cycle arrest, which was consistent with our previous result (8). We have reported that mitochondrial Bax protein expression was up-regulated after incubation with evodiamine (9). These observations suggested that the activation of p53 increased the expression of Bax. Furthermore, SIRT1 inactivation might be involved in p53- and Bax-dependent cell death induced by evodiamine.

Effects of PI3-K and PKC on evodiamine-induced inhibition of ERK in A375-S2 cell death

Previously reports have shown that PI3-K and PKC exist upstream of the MAPK cascade, especially in regulating the function of $\operatorname{ERK}(27,28)$. Moreover, protein expression and phosphorylation of ERK were

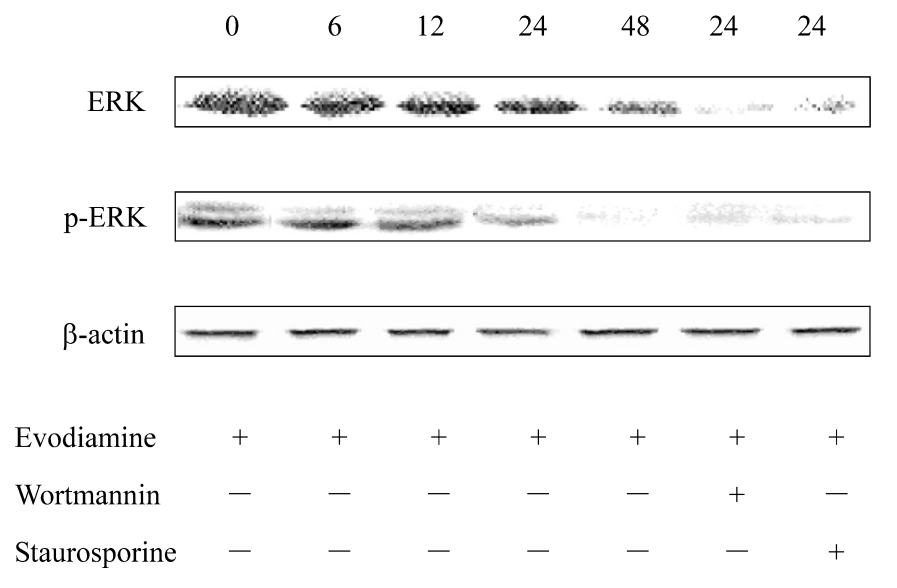

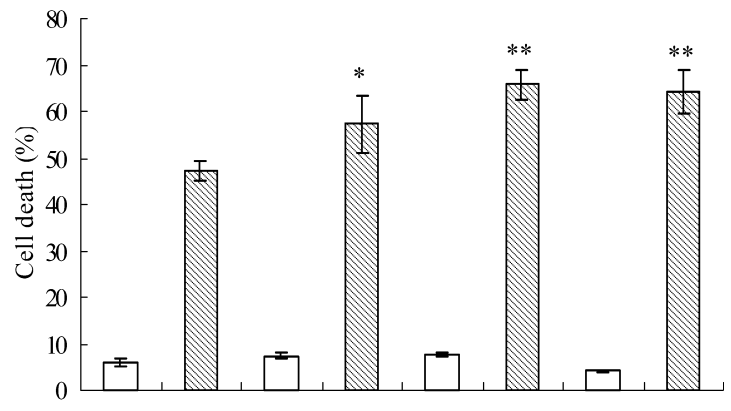

$\begin{array}{lllllllll}\text { Evodiamine } & - & + & - & + & - & + & - & + \\ \text { Wortmannin } & - & - & + & + & - & - & - & - \\ \text { Staurosporine } & - & - & - & - & + & + & - & - \\ \text { PD98059 } & - & - & - & - & - & - & + & +\end{array}$

Fig. 4. Effects of kinase inhibitors on evodiamine-induced A375S2 cell death. A375-S2 cells were treated with $15 \mu \mathrm{M}$ evodiamine for 24 h. $200 \mathrm{nM}$ wortmannin, $20 \mathrm{nM}$ staurosporine, or $10 \mu \mathrm{M}$ PD98059 was added $1 \mathrm{~h}$ prior to the treatment with evodiamine. $\mathrm{n}=3$. Mean \pm S.D. $* P<0.05, * * P<0.01$ vs evodiamine alone group.

down-regulated by evodiamine (9). Therefore, wortmannin (inhibitor of PI3-K) and staurosporine (inhibitor of PKC) were applied to investigate the roles of PI3-K and PKC pathways in evodiamine-induced cell death. After 24-h incubation, similar to the effect of the ERK inhibitor PD98059, both $200 \mathrm{nM}$ wortmannin and $20 \mathrm{nM}$ staurosporine augmented the cytotoxic effect of evodiamine (Fig. 4). These results demonstrated inhibition of PI3-K/PKC as well as the subsequent ERK cascade might contribute to evodiamine-induced cell death.

To confirm whether PI3-K and PKC can influence ERK signaling, effects of inhibitors of PI3-K and PKC on ERK expression and its phosphorylation were examined. When A375-S2 cells were treated with evodiamine for $24 \mathrm{~h}$, inhibition of PI3-K and PKC
$-44 \mathrm{kDa}$

$-42 \mathrm{kDa}$

$-44 \mathrm{kDa}$

$-42 \mathrm{kDa}$

$-46 \mathrm{kDa}$
Fig. 5. Effects of PI3-K and PKC inhibitors on evodiamine-induced inhibition of ERK in A375-S2 cell death. The cells were treated with $15 \mu \mathrm{M}$ evodiamine for the indicated time in the presence or absence of $200 \mathrm{nM}$ wortmannin and $20 \mathrm{nM}$ staurosporine, followed by Western blot analysis for detection of protein expressions. Triplicate experiments gave similar results. 
further attenuated protein expression of ERK and its phosphorylation (Fig. 5). In view of these data, downregulation of ERK induced by evodiamine in A375-S2 cell death might be related to the inactivation of the PI3-K/PKC survival pathway.

SIRT1 inactivation and p53 activation in response to evodiamine is dependent on PI3-K and PKC, but did not require $E R K$

A375-S2 cells were pretreated with wortmannin, staurosporine, and PD98059 for $60 \mathrm{~min}$ and than cultured with $15 \mu \mathrm{M}$ evodiamine for another $24 \mathrm{~h}$. The results showed that in the presence of wortmannin and staurosporine, SIRT1 expression reduced by evodiamine was further attenuated (Fig. 6), and increased expressions of p53 and phosphorylated p53 induced by evodiamine were also down-regulated (Fig. 7). However, PD98059 did not have such effects (Figs. 6 and 7). These results suggested that the PI3-K/PKC pathway but not ERK were related to SIRT1 inactivation and p53 activation induced by evodiamine.

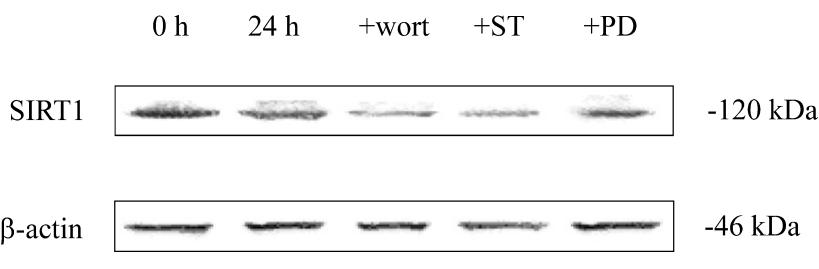

Fig. 6. Decreased expression of SIRT1 was dependent on inactivation of PI3-K and PKC, but did not require ERK. The cells were pretreated with $200 \mathrm{nM}$ wortmannin, $20 \mathrm{nM}$ staurosporine, and $10 \mu \mathrm{M}$ PD98059 for $1 \mathrm{~h}$, followed by the addition of $15 \mu \mathrm{M}$ evodiamine. After $24 \mathrm{~h}$, cell lysates were separated by $12 \%$ SDS-PAGE, and the SIRT1 protein band was detected by Western blot analysis. Triplicate experiments gave similar results.
The balance of Bax/Bcl-2 regulated by PI3-K and $P K C$ in A375-S2 cell death

As we have previously reported, increased expression ratio of $\mathrm{Bax} / \mathrm{Bcl}-2$ were involved in evodiamineinduced A375-S2 cell apoptosis (9) (Fig. 8). To further investigate the roles of PI3-K/PKC on Bcl-2 family proteins, the cells were incubated with evodiamine in the presence of the PI3-K inhibitor wortmannin and PKC inhibitor staurosporine for $24 \mathrm{~h}$. Wortmannin partially blocked Bcl-2 expression, while it enhanced the expressive level of Bax; and staurosporine down-regulated Bcl-2 expression without affecting the expression of Bax (Fig. 8). The results suggested that in evdiamineinduced cell death, increased expression ratio of $\mathrm{Bax} / \mathrm{Bcl}-2$ was dependent on the inactivation of the $\mathrm{PI} 3-\mathrm{K} / \mathrm{PKC}$ survival pathway.

\section{Discussion}

A major aim of the current study was to define how engagements of PI3-K and PKC pathways affect A375$\mathrm{S} 2$ cell death induced by evodiamine. It was possible

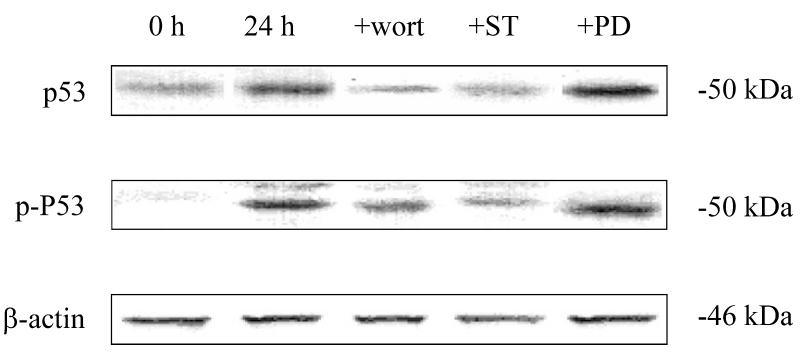

Fig. 7. $\mathrm{PI} 3-\mathrm{K}$ and $\mathrm{PKC}$ were required for evodiamine-induced $\mathrm{p} 53$ activation. The cells were treated with $15 \mu \mathrm{M}$ evodiamine in the presence or absence of $200 \mathrm{nM}$ wortmannin, $20 \mathrm{nM}$ staurosporine, and $10 \mu \mathrm{M}$ PD 98059 for $24 \mathrm{~h}$. Then the expression of total p53 and phosphor-p53 were determined by Western blot analysis. Triplicate experiments gave similar results.

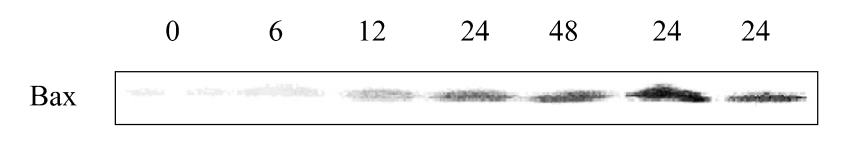

Time (h)

$-21 \mathrm{kDa}$

Bcl-2

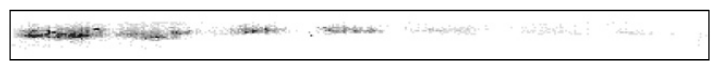

$\beta$-actin

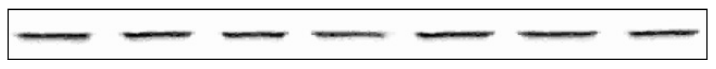

$-46 \mathrm{kDa}$
Fig. 8. The balance of $\mathrm{Bax} / \mathrm{Bcl}-2$ regulated by PI3-K and PKC. The cells were treated with $15 \mu \mathrm{M}$ evodiamine for the indicated time in the presence or absence of $200 \mathrm{nM}$ wortmannin and $20 \mathrm{nM}$ staurosporine, followed by Western blot analysis for detection of Bax and Bcl-2 protein expression. Triplicate experiments gave similar results. 
that inactivation of SIRT1 and activation of $\mathrm{p} 53$ contributed to apoptosis in response to the administration of evodiamine. Importantly, wortmannin, staurosporine, and PD98059 significantly augmented evodiamineinduced cell death.

SIRT1 is known to inhibit stress-induced apoptosis (19). SIRT1 prevents p53 and Bax from mediating apoptosis by deacetylation of them $(20,21)$. In the present study, evodiamine reduced SIRT1 expression and induced corresponding activation of p53 and Bax. In addition, wortmannin and staurosporine attenuated SIRT1 expression by inhibiting PI3-K and PKC, respectively. These results indicated that SIRT1 inactivation was associated with p53- and Bax-mediated cell death induced by evodiamine, and this inactivation might be caused by the inhibition of the PI3-K/PKC survival pathway. The tumor suppressor protein $\mathrm{p} 53$ acted on Bax synthesis rather than induction of $\mathrm{p} 21$, indicating that evodiamine was able to induce A375-S2 cell death at each phase without affecting cell cycle distribution (8).

It has been reported that activation of p53 is dependent on phosphorylation by DNA-PK (DNA-dependent protein kinase), a member of the PI3-K family $(33,34)$. $\mathrm{PI} 3-\mathrm{K}$ is also required for the activation of the PKC pathway (27), which promotes cell survival via induction of ERK (35) and Bcl-2 (27, 30). Since p53 lies downstream of PI3-K, there must exist close links among p53 and the signal from PI3-K to PKC and the subsequent MAPK/ERK cascade. As expected, wortmannin as well as staurosporine partially blocked expression of p53 and phosphorylation of p53 in the presence of evodiamine for $24 \mathrm{~h}$. Moreover, ERK expression and its phosphorylation were further reduced by wortmannin and staurosporine, but PD98059 did not affect p53 content and its phosphorylation. Taken together, the PI3-K/PKC pro-apoptotic pathway was required for activation of $\mathrm{p} 53$ in evodiamine-induced cell death. Whereas the constitutive activation of the PI3-K/PKC survival pathway seemed to enhance the activity of ERK, which protected A375-S2 cells from apoptosis and necrosis induced by evodiamine (9).

The proapoptotic protein Bax and antiapoptotic protein $\mathrm{Bcl}-2$ are known to regulate stress-induced cell death (36). Our present study showed that increased expression of Bax and decreased expression of $\mathrm{Bcl}-2$ were involved in evodiamine-induced cell death. Both wortmannin and staurosporine reduced $\mathrm{Bcl}-2$ expression confirmed that PI3-K/PKC directly contributed to Bcl-2 increased expression, whereas this process was inhibited by evodiamine. Staurosporine did not change Bax protein expression, suggesting that inactivation of SIRT1 may have counteracted the inhibition of $\mathrm{p} 53$ by
PKC; and increased Bax expression by wortmannin might be associated with some negative regulation by PI3-K, not only including SIRT1. Therefore, PI3-K might function in another pathway that prevents cell death, other than its proapoptotic pathway through activation of $\mathrm{p} 53$.

In this study, we made a speculation about the roles of $\mathrm{PI} 3-\mathrm{K}$ and $\mathrm{PKC}$ in modulating the signaling transduction pathway that might be involved in evodiamine-induced A375-S2 cell death. These events constitute a sequence that proceeds from PI3-K/PKC through SIRT1, p53, and ERK activation to regulation of $\mathrm{Bax} / \mathrm{Bcl}-2$ expression ratio. On one hand, PI3-K/PKC led to p53 activation resulting in cell death; and on the other hand, they protected A375-S2 cells from evodiamine-induced cell death through SIRT1, ERK activation, and decreased $\mathrm{Bax} / \mathrm{Bcl}-2$ ratio.

Thus, it is conceivable that the potentiating effects of wortmannin and staurosporine on evodiamine-induced cell death reflect the inhibition of the PI3-K/PKC survival pathway and the initiation of pro-apoptotic PI3-K/PKC signaling because human melanoma A375S2 cells have high sensitivity to the proinflammatory cytokine IL-1 and IL-1 was capable of inducing apoptosis in A375-S2 cells (37). The future aim of our study is to find out the cross pathways in natural compound (evodiamine)- and IL-1-induced cell death. Therefore, our present studies on the machinery of evodiamine-induced cell death and cross-link between evodiamine and the IL-1 signal transduction pathway might be useful as immunopharmacological bases of cancer therapy.

\section{References}

1 Kobayashi Y, Nakano Y, Hoshikuma K, Yokoo Y, Kamiya T. The bronchoconstrictive action of evodiamine, an indoloquinazoline alkaloid isolated from the fruits of Evodia rutaecarpa, on guinea-pig isolated bronchus: possible involvement of vanilloid receptors. Planta Med. 2000;66:526-530.

2 Yoshizumi M, Houchi H, Ishimura Y, Hirose M, Kitagawa T, Tsuchiya K, et al. Effect of evodiamine on catecholamine secretion from bovine adrenal medulla. J Med Invest. 1997;44: 79-82.

3 Chiou WF, Chou CJ, Shum AY, Chen CF. The vasorelaxant effect of evodiamine in rat isolated mesenteric arteries: mode of action. Eur J Pharmacol. 1992;215:277-283.

4 Chiou WF, Liao JF, Chen CF. Comparative study of the vasodilatory effects of three quinazoline alkaloids isolated from Evodia rutaecarpa. J Nat Prod. 1996;59:374-378.

5 Matsuda H, Wu JX, Tanaka T, Iinuma M, Kubo M. Antinociceptive activities of $70 \%$ methanol extract of Evodiae fructus and its alkaloidal components. Biol Pharm Bull. 1997;20:243-248.

6 Fei XF, Wang BX, Li TJ, Tashiro S, Minami M, Xing DJ, et al. Evodiamine, a constituent of Evodiae Fructus, induces anti- 
proliferating effects in tumor cells. Cancer Sci. 2003;94:92-98.

7 Ogasawara M, Matsubara T, Suzuki H. Inhibitory effects of evodiamine on in vitro invasion and experimental lung metastasis of murine colon cancer cells. Biol Pharm Bull. 2001; 24:917-920.

8 Zhang Y, Wu LJ, Tashiro S, Onodera S, Ikejima T. Evodiamine induces tumor cell death through different pathways: apoptosis and necrosis. Acta Pharmacol Sin. 2004;25:83-89.

9 Zhang Y, Wu LJ, Tashiro S, Onodera S, Ikejima T. Intracellular regulation of evodiamine-induced A375-S2 cell death. Biol Pharm Bull. 2003;26:1543-1547.

10 Ciciarello M, Mangiacasale R, Casenghi M, Limongi MZ, D'Angelo M, Soddu S, et al. p53 displacement from centrosomes and p53-mediated G1 arrest following transient inhibition of the mitotic spindle. J Biol Chem. 2001;276:19205-19213.

11 Karpinich NO, Tafani M, Rothman RJ, Russo MA, Farber JL. The course of etoposide-induced apoptosis from damage to DNA and p53 activation to mitochondrial release of cytochrome $c$. J Biol Chem. 2002;277:16547-16552.

12 Zhou BB, Elledge SJ. The DNA damage response: putting checkpoints in perspective. Nature. 2000;408:433-439.

13 Jabbur JR, Huang P, Zhang W. DNA damage-induced phosphorylation of $\mathrm{p} 53$ at serine 20 correlates with p21 and Mdm-2 induction in vivo. Oncogene. 2000;19:6203-6208.

14 Kroemer G. The proto-oncogene Bcl-2 and its role in regulating apoptosis. Nat Med. 1997;3:614-620.

15 Weinmann P, Gaehtgens P, Walzog B. Bcl- $\mathrm{x}_{\mathrm{L}^{-}}$and Bax- $\alpha$ mediated regulation of apoptosis of human neutrophils via caspase-3. Blood. 1999;93:3106-3115.

16 Scorrano L, Oakes SA, Opferman JT, Cheng EH, Sorcinelli MD, Pozzan $\mathrm{T}$, et al. BAX and BAK regulation of endoplasmic reticulum $\mathrm{Ca}^{2+}$ : a control point for apoptosis. Science. 2003; 300:135-139.

17 Jerry EC, Tomomi K, Lisa BH, Nathalie MD, Donald DN, Martin S, et al. Direct activation of Bax by p53 mediates mitochondrial memberane permeabilization and apoptosis. Science. 2004;303:1010-1014.

18 Wu Z, Wu LJ, Li LH, Tashiro S, Onodera S, Ikejima T. P53mediated cell cycle arrest and apoptosis induced by shikonin via a caspase-9-dependent mechanism in human malignant melanoma A375-S2 cells. J Pharmacol Sci. 2004;94:166-176.

19 Wood JG, Rogina B, Lavu S, Howitz K, Helfand SL, Tatar M, et al. Sirtuin activators mimic caloric restriction and delay ageing in metazoans. Nature. 2004;430:686-689.

20 Vaziri H, Dessain SK, Eaton EN, Imai SI, Frye RA, Pandita TK, et al. hSIR2 (SIRT1) functions as an NAD-dependent p53 deactylase. Cell. 2001;107:149-159.

21 Cohen HY, Miller C, Bitterman KJ, Wall NR, Hekking B, Kessler B, et al. Calorie restriction promotes mammalian cell survival by inducing the SIRT1 deacetylase. Science. 2004;305: 390-392.

22 Peter S, Frank M. Phosphoinositide 3-OH kinase (PI3K) and $\mathrm{PKB} / \mathrm{Akt}$ delay the onset of p53-mediated, transcriptionally dependent apoptosis. J Biol Chem. 1999;274:24263-24269.

23 Li F, Guangnan L, Guizhong L, Sam WL, Stuart AA. p53 induction of heparin-binding EGF-like growth factor counteracts p53 growth suppression through activation of MAPK and PI3K/Akt signaling cascades. EBMO J. 2001;20:1931-1939.

24 Punn A, Mockridge JW, Farooqui S, Marber MS, Heads RJ. Sustained activation of $\mathrm{p} 42 / \mathrm{p} 44$ mitogen-activated protein kinase during recovery from stimulated ischaemia mediated adaptive cytoprotection in cardiomyocytes. Biochem J. 2000; 350:330-335.

25 Petrache I, Choi ME, Otterbein LE, Chin BY, Mantell LI, Horowitz S, et al. Mitogen-activated protein kinase pathway mediates hyperoxia-induced apoptosis in cultured macrophage cells. Am J Physiol. 1999;277:L589-L595.

26 Musashi M, Ota S, Shiroshita N. The role of protein kinase C isoforms in cell proliferation and apoptosis. Int $\mathrm{J}$ Hematol. 2000;72:12-19.

27 Rocha AB, Mans DRA, Regner A, Schwartsmann G. Targeting protein kinase $\mathrm{C}$ : new therapeutic opportunities against highgrade malignat gliomas? Oncologist. 2002;7:7-33.

28 Moriya S, Kazlauskas A, Akimoto K, Hirai SI, Mizuno K, Takenawa $\mathrm{T}$, et al. Platelet-derived growth factor activates protein kinase $\mathrm{C}$ epsilon through redundant and independent signaling pathways involving phosphatidylinositol 3-kinase. Proc Natl Acad Sci USA. 1996;93:151-155.

29 Schonwasser DC, Marais RM, Marshall CJ, Parker PJ. Activation of the mitogen-activated protein kinase/extracellular signal-regulated kinase pathway by conventional, novel, and atypical protein kinase C isotypes. Mol Cell Biol. 1998;18:790798.

30 Haldar S, Jena N, Croce CM. Inactivation of Bcl-2 by phosphorylation. Proc Natl Acad Sci USA. 1995;92:4352-4356.

31 Kitamura Y, Miyamura A, Takata K, Inden M, Tsuchiya D, Nakamura K, et al. Possible involvement of both endoplasmic reticulum-and mitochondria-dependent pathways in thapsigargininduced apoptosis in human neuroblastoma SH-SY5Y cells. J Pharmacol Sci. 2003;92:228-236.

32 Suzuki K, Hino M, Kutsuna H, Hato F, Sakamoto C, Takahashi T. Selective activation of $\mathrm{p} 38$ mitogen-activated protein kinase cascade in human neutrophils stimulated by IL-1beta. J Immunol. 2001;167:5940-5947.

33 Jackson SP. DNA-dependent protein kinase. Int J Biochem Cell Biol. 1997;29:935-938.

34 Zhang CL, Wu LJ, Zuo HJ, Tashiro S, Onodera S, Ikejima T. Cytochrome $c$ release from oridonin-treated apoptotic A375-S2 cells is dependent on p53 and extracellular signal-regulated kinase activation. J Pharmacol Sci. 2004;96:155-163.

35 Ahn JH, Park SM, Cho HS, Lee MS, Yoon JB, Vilcek J, et al. Non-apoptotic signaling pathways activated by soluble Fas ligand in serum-starved human fibroblasts. J Biol Chem. 2001;276:47100-47106.

36 Pastorino JG, Tafani M, Rothman RJ, Marcineviciute A, Hock JB, Farber JL. Functional consequences of the sustained or transient activation by Bax of the mitochondrial permeability transition pore. J Biol Chem. 1999;274:31734-31739.

37 Wang C, Wang MW, Tashiro S, Onodera S, Ikejima T. Human interleukin- $\beta$ induces $\mathrm{A} 375-\mathrm{S} 2$ human melanoma apoptosis through caspase pathway. Chin J Pathophysiol. 2004;20:11381143 . 